\title{
Comparative analysis of human papillomavirus detection by dot blot hybridisation and non-isotopic in situ hybridisation
}

\author{
G Troncone, S M Anderson, C S Herrington, M L de Angelis, H Noell, J A Chimera, \\ J O'D McGee
}

\begin{abstract}
Aims: To determine the relative diagnostic performance of non-isotopic in situ hybridisation (NISH) and a dot-blot assay for detecting human papillomavirus (HPV) on exfoliated cervical cells; and to correlate the results with cytopathological assessment.

Methods: Cervical smears and cytological samples were obtained from 122 patients during the same clinical examination and the presence of HPV sequences determined by NISH and dot-blot analysis, respectively.

Results: Dot-blot analysis gave an autoradiographic signal in 15 of $121(12 \cdot 4 \%)$ cases, while NISH detected viral genomes in 38 of $114(33.3 \%)$ cases. Even in the presence of koilocytosis, where vegetative replication of the virus occurs, NISH was positive in over twice as many cases as dot-blot analysis (NISH $\mathbf{9 0 \%}$, dot-blot $40 \%$, while in smears within normal cytological limits, where the viral copy number is likely to be considerably lower, the differences were more striking (NISH $31 \%$, dot-blot $5 \%$ ).

Conclusions: These data show that NISH on cytological smears is more sensitive than a standardised dot-blot hybridisation assay for detecting HPV infection in cytological material and is therefore a more appropriate screening tool.
\end{abstract}

(f Clin Pathol 1992;45:866-870)

Infection with certain types of human papillomavirus (HPV 16, 18, 31, 33, 35, 45, 52, 56) has been increasingly implicated as an early event in the natural history of high grade squamous cervical dysplasia (CIN 2-3) and invasive carcinoma. ${ }^{1}$ Women with cervical HPV infection may therefore be at greater risk of developing preinvasive and invasive squamous epithelial lesions. ${ }^{1}$ Standard histopathological and cytopathological testing does not, however, detect non-productive viral infection, or the presence of integrated virus. ${ }^{2-4}$ This can only be demonstrated by nucleic acid hybridisation. Consequently, exfoliated cervicovaginal cells have been tested extensively for the presence of HPV DNA in clinically normal and abnormal population groups. ${ }^{5-17}$ In these studies, the presence of HPV DNA in cells or DNA obtained by cervical swab or lavage has been assessed by a variety of molecular techniques, including filter hybridisation, ${ }^{5-8}$ non- isotopic in situ hybridisation (NISH) $)^{9-12}$ and PCR ${ }^{14-17}$ In situ hybridisation has the advantage over other methods in that it permits unequivocal localisation of HPV genomes to epithelial cells and thereby obviates the risk of false positive results due to laboratory or clinical contamination.

To date, only one diagnostic test is commercially available for HPV screening and typing. This is a filter hybridisation assay, based on the use of radiolabelled $\left[{ }^{32} \mathrm{P}\right] \mathrm{RNA}$ probes. The sensitivity of this test has not previously been compared with NISH. The aims of this study were twofold: first, to assess the relative diagnostic performance of NISH and the dot-blot hybridisation assay and second, to correlate these data with the cytopathological assessment. To address these issues cervical samples were collected from 122 women undergoing routine gynaecological examination. The samples were tested for the presence of HPV by dot-blot and NISH in separate laboratories and the results evaluated double blind for each cytological diagnostic group.

\section{Methods}

Women ( $\mathrm{n}=122$ ) undergoing routine gynecological examination were recruited from two sites: Greenville, North Carolina and San Diego, California, USA between March and May 1990. A cervical swab was taken and suspended in medium provided in the dot-blot sample collection kit (ViraPap, ViraType, Digene Diagnostics, Inc, Silver Spring, Maryland, USA). A cervical smear was taken at the same time from each patient and fixed immediately in the standard way. NISH was performed on the smear while the suspended cells, from the swab, were assayed for the presence of HPV and HPV type by the dot-blot assay. After NISH was performed, smears were counterstained with haematoxylin and assessed both cytopathologically and for the presence of NISH signal. ${ }^{11}$ Cytopathology, NISH (Oxford University) and dot-blot hybridisation (Roche Biomedical Laboratories) were performed double blind and the results compared.

\section{DOT-BLOT FILTER HYBRIDISATION}

Cell disruption, denaturation, and immobilisation of DNA on to nylon filters, hybridisation, and detection were carried out according to the manufacturer's instructions. Briefly, the procedure was as follows: specimens were incubated with sample preparation reagent at $37^{\circ} \mathrm{C}$ for one hour to complete cell lysis. DNA denaturation was achieved by incubation in 
alakaline solution. The DNA was bound to a nylon filter under vacuum and the membrane transferred to a reaction tray, covered with prehybridisation buffer and incubated at $60^{\circ} \mathrm{C}$ for 30 minutes. The hybridisation mix contained a cocktail of ${ }^{32} \mathrm{P}$-RNA transcripts to HPV types $6,11,16,18,31,33$ and 35 . The membrane was hybridised at $60^{\circ} \mathrm{C}$ for two hours and nonspecifically bound probe was removed by RNase treatment and low and high stringency post-hybridisation washes. Autoradiography was then carried out at $-70^{\circ} \mathrm{C}$ for $48-72$ hours and the presence of HPV DNA in the sample was determined by the presence of an autoradiographic signal. Samples positive by dot-blot (ViraPap) were further HPV typed by Vira Type assay, which differs only in that three replicate membranes are hybridised with separate cocktails of complementary radiolabelled probes (HPV 6/11; 16/18 and 31/33/35).

\section{NISH ON CERVICAL SMEARS}

In situ hybridisation was performed on routine cervical smears, as previously described. ${ }^{11}$ Briefly, smears were washed in freshly prepared methanol/acetic acid $(3: 1=v / v)$, fixed in $4 \%$ paraformaldehyde $(\mathrm{w} / \mathrm{v})$ in PBS (PBS $=10 \mathrm{mM}$ phosphate, $150 \mathrm{mM} \mathrm{NaCl}$, pH 7.4), endogenous peroxidase activity blocked in peroxide/azide and nucleic acids unmasked using $1 \mu \mathrm{g} / \mathrm{ml}$ proteinase $\mathrm{K}$. Smears were then postfixed in paraformaldehyde, washed in PBS and air dried. A cocktail of

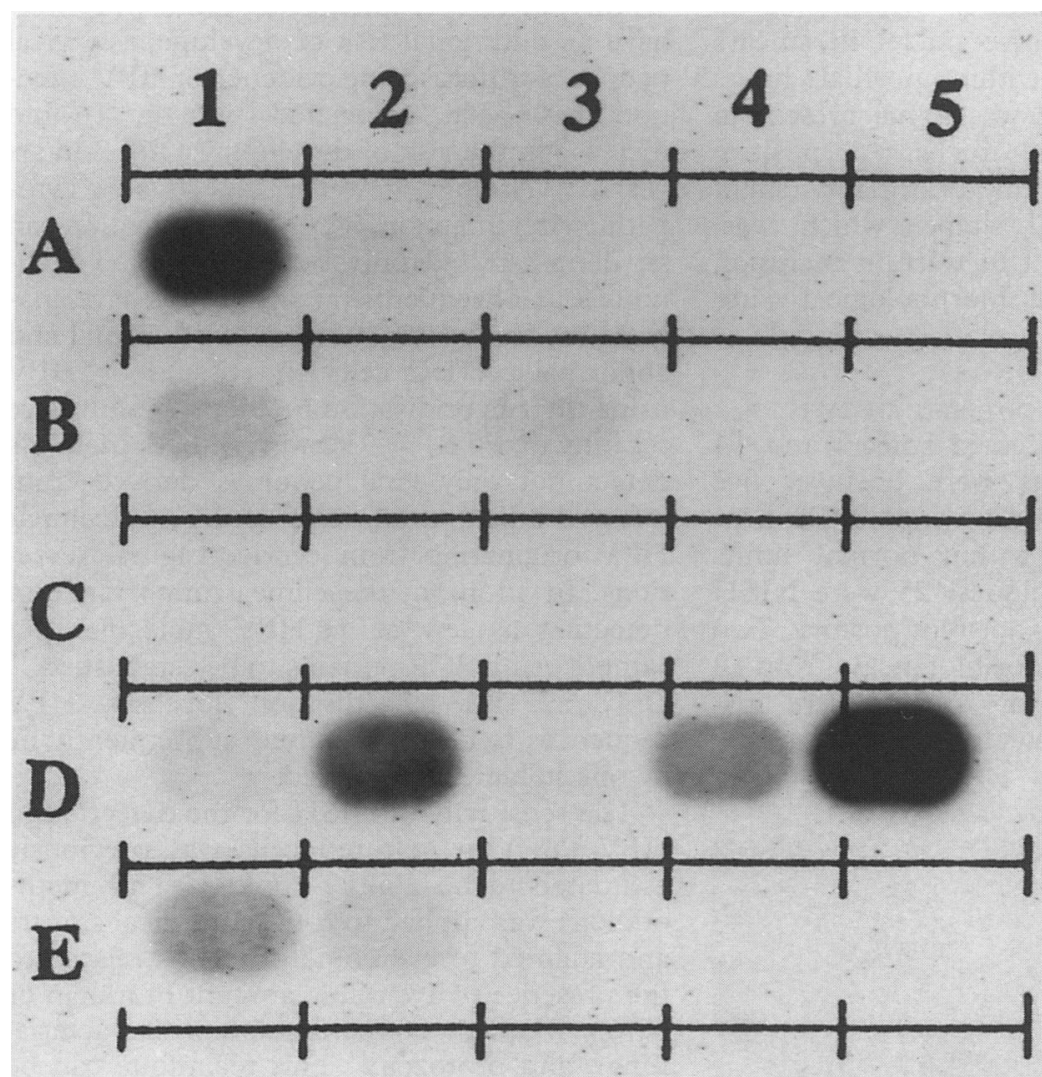

Figure 1 A representative autoradiograph of the dot-blot assay for HPV. The dot-blot membrane includes a high positive (A1), low positive (B1), and negative control (C1). Samples that produce an image equal to or greater than the low positive control are considered positive for one or more viral types from the group HPV $6,11,16,18,31$, 33 , and/or 35. Examples of positive specimens are shown in rows $D$ and $E$. Low positive control $=2 \times 10^{4}$ disrupted $\mathrm{HeL}$ a cells; high positive control $=1 \times 10^{5}$ disrupted HeLa cells; negative control $=5 \times 10^{5}$ disrupted HTB-31 cells.
HPV 6, 11, 16, 18, 31 and 33 probes $(2 \mathrm{ng} / \mu 1$ each) labelled with digoxigenin by nick translation ${ }^{18}$ was added to the hybridisation mix containing $50 \%(\mathrm{v} / \mathrm{v})$ formamide, $5 \%$ $(\mathrm{w} / \mathrm{v})$ dextran sulphate, $2 \times \mathrm{SSC}(1 \times$ SSC $=0.15 \mathrm{M}$ i sodium chloride, $0.015 \mathrm{M}$

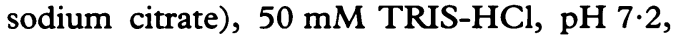
$5 \mathrm{mM}$ EDTA, $0 \cdot 1 \%(\mathrm{w} / \mathrm{v})$ sodium pyrophosphate $0 \cdot 2 \%(\mathrm{w} / \mathrm{v})$ polyvinylpyrollidine 400000 molecular weight, $0 \cdot 2 \%$ (w/v) Ficoll 400000 molecular weight and $200 \mathrm{ng} / \mu \mathrm{l}$ sheared human DNA. Target DNA and probes were denatured simultaneously at $95^{\circ} \mathrm{C}$ for $15 \mathrm{~min}$ utes and hybridised at $42^{\circ} \mathrm{C}$ for two hours. ${ }^{18}$ After hybridisation, smears were washed twice in $4 \times$ SSC and soaked in blocking agent (TBT) comprising $50 \mathrm{mM}$ TRIS- $\mathrm{HCl}$ (pH 7.2). $100 \mathrm{mM} \mathrm{NaCl}, 1 \mathrm{mM} \mathrm{MgCl}_{2}$ (TBS) containing $3 \%(\mathrm{w} / \mathrm{v})$ bovine serum albumin, $0.05 \%$ (v/v) Triton X-100. Smears were sequentially incubated in monoclonal anti-digoxin (Sigma UK), biotinylated rabbitanti mouse $F\left(a b^{\prime}\right)_{2}$ fragment (Dako UK), and avidin peroxidase conjugate in TBT containing $5 \%(w / v)$ non-fat milk (Cadbury UK). ${ }^{19} \mathrm{~A}$ red NISH signal was developed by incubation in 3-amino-9-ethylcarbazole, $\mathrm{H}_{2} \mathrm{O}_{2}$ (Zymed USA) for 10 minutes. The reaction was stopped by washing in water smears counterstained progressively with haematoxylin for 10-15 seconds and mounted in glycerol jelly. ${ }^{20}$

CYTOPATHOLOGICAL ASSESSMENT OF NISH SMEARS After NISH, the smears were counterstained with haematoxylin, cytologically assessed, and divided into five diagnostic groups. The first group were assessed as being within normal limits. "Minor" wart virus infection was diagnosed on the basis of the following morphological criteria: squamous cells arranged in a concentric manner with cohesive rounded margins and abnormal nuclei. When these changes were accompanied by koilocytosis, a cytological diagnosis of wart virus infection (WVI) was made. The final diagnostic group contained dyskaryotic smears showing nuclear enlargement with a high nucleolar:cytoplasmic ratio.

The two methods were compared using either the $\chi^{2}$ test for independent samples (where all expected values were greater than 5) or a two-tailed Fisher's exact probability test. $^{21}$

\section{Results}

DOT-BLOT ANALYSIS

Dot-blot hybridisation gave an autoradiographic signal (fig 1) in 15 of $121(12.4 \%$ ) cases. One case was not analysed due to an excessively high red cell content. HPV 6/11 were found alone in one case, HPV 16/18 alone in three cases, and HPV 31/33/35 alone in nine cases. Two cases produced multiple signals: in one HPV6/11 and HPV31/33/35 were present and in the other HPV16/18 and HPV 31/33/35. Correlation of these results with the cytopathological diagnosis (table 1) demonstrates that four of $81(5 \%)$ smears 
Table 1 Cervical cytopathology and HPV detection by dot-blot and NISH

\begin{tabular}{lclrl}
\hline Cytopathology & $n=$ & Dot-blot & \multicolumn{1}{l}{ NISH } & p Value \\
\hline Normal & $82^{\star}$ & $4(5 \%)$ & $25(31 \%)$ & $\mathrm{p}<0.001 \dagger$ \\
Inflammatory & 12 & $4(33 \%)$ & $2(17 \%)$ & $\mathrm{p}>0.05 \ddagger$ \\
Minor wart virus changes & 6 & $1(17 \%)$ & $1(17 \%)$ & \\
Wart virus infection & 10 & $4(40 \%)$ & $9(90 \%)$ & $\mathrm{p}>0.05 \ddagger$ \\
Mild/moderate dyskaryosis & 4 & $1(25 \%)$ & $1(25 \%)$ & \\
Not determined & 8 & $1(12.5 \%)$ & ND &
\end{tabular}

*In one case with normal cytopathology, which was negative by NISH, dot-blot analysis was not possible due to an excessively high red cell concentration in the sample.

ND Not determined due to excessive non-specific substrate deposition.

$+\chi^{2}$

$\dagger \chi^{2}$
$\ddagger$ Fisher's exact probability test (two-tailed).

within normal limits, four of $12(33 \%)$ inflammatory smears, one of six $(17 \%)$ minor wart virus infection, four of $10(40 \%)$ WVI smears and one of four $(25 \%)$ dyskaryotic smears were dot-blot positive. In eight cases cytopathological assessment was not possible due to nonspecific substrate deposition: one of these cases was dot-blot positive for HPV 31/33/35.

NISH ANALYSIS

In eight cases the NISH result was uninterpretable due to non-specific substrate deposition. Using a cocktail of HPV probes $(6,11$, $16,18,31,33$ ) on the remaining 114 cases, $\mathrm{NISH}$ detected viral genomes in 38 cases (33.3\% (fig 2)). HPV DNA was found in 25 of $82(31 \%)$ smears within normal cytopathological limits, two of $12(17 \%)$ inflammatory smears, one of six $(17 \%)$ minor wart virus infection, nine of $10(90 \%)$ smears showing diagnostic features of WVI and in one of four (25\%) dyskaryotic smears. Morphological analysis of NISH positive nuclei in smears diagnosed as being within normal limits showed that in no case was signal present in morphologically normal nuclei. All positive cells showed minor nuclear abnormality (slight enlargement, abnormal shape) which was, nevertheless, insufficient to warrant inclusion in a defined abnormal morphological category.

COMPARISON OF NISH AND DOT-BLOT ANALYSIS

Overall, $38 \mathrm{NISH}$ processed smears and 14 corresponding dot-blots were positive; five cases were dot-blot positive and NISH negative. Of 81 smears within normal limits analysed by both techniques, 25 were NISH $(29.6 \%)$ and four (5\%) dot-blot positive. Two NISH smears and four dot-blot assays from 12 patients with inflammatory smears were positive. Of six smears showing minor diagnostic

Figure 2 A routine cervical smear was hybridised with a cocktail of probes for HPV 6, 11, $16,18,31$ and 33 and detected as described. HPV signal is present within an epithelial cell nucleus (arrows). Note the absence of signal in neutrophil polymorphs and another epithelial cell nucleus (arrowhead).
Table 2 Correlation of NISH and dot-blot hybridisation

\begin{tabular}{lll}
\hline NISH & Dot-blot hybridisation & \\
\hline & + & - \\
+ & 9 & 29 \\
- & 5 & 70 \\
\hline
\end{tabular}

cytological criteria of HPV infection, two were positive by NISH and one by dot-blot. Of 10 smears containing koilocytes, nine $(90 \%)$ were positive by NISH and four (40\%) by dot-blot. Of four cases with evidence of dyskaryosis, one (25\%) was both NISH and dot-blot positive.

The correlation of NISH and dot-blot hybridisation, regardless of cytopathological diagnosis, is shown in table 2 . Five cases were dot-blot positive and NISH negative; and 29 cases were NISH positive, dot-blot negative.

In each dot-blot assay the controls included by the manufacturers gave the expected autoradiographic signal. Controls in all NISH experiments included $\mathrm{CaSki}$ cell smears (which contain integrated HPV $16^{22}$ ); and cytologically normal cervical smears (from a separate cohort). These were hybridised with HPV 16 and total human DNA, respectively. ${ }^{23}$ Multiple nuclear signals were obtained in CaSki cells ${ }^{20}$ and total human DNA labelled every nucleus in control smears.

\section{Discussion}

Women infected with specific HPV types may have an additional risk of developing cervical neoplasia. Microscopic evidence of HPV infection has been associated with a 16-fold increase in the risk of developing CIN 3 in six years. ${ }^{24}$ Cytology, however, detects only cytopathic viral infection, while latent infection can be demonstrated only by hybridisation techniques. ${ }^{2}$ Consequently, many groups have analysed the frequency of infection of normal and abnormal cervical cells and tissues by HPV using filter hybridisation methods ${ }^{5-8}$ and more recently by PCR. ${ }^{14-17}$ However, these methods detect not only viral genomes derived from infected cells, but may also detect extracellular HPV originating from cervico-vaginal secretions. In addition, the clinical importance of detecting as few as $10 \mathrm{HPV}$ molecules per sample using PCR remains to be established. ${ }^{16}$ Only in situ hybridisation localises HPV sequences to cells which may subsequently be cytopathologically assessed.

The sensitivity of NISH for the detection of HPV DNA in cultured cells was previously estimated to be $2 \cdot 5-12$ copies. $^{19}$ This methodology was applied to routine cervical smears and adapted to overcome problems related to the presence of a variable amount of mucin or to the frequent contamination with bacteria, fungi, and protozoa. ${ }^{11}$ This technique can be performed using basic laboratory equipment within one working day and therefore has a potential role in routine cervical screening.

At present, only one dot-blot diagnostic test is commercially available for HPV detection in exfoliated cervical cells. This is a filter hybrid- 
isation assay based on the use of radiolabelled $\left[{ }^{32} \mathrm{P}\right] \mathrm{HPV}$ probes. These hybridise with the target HPV DNA which is derived from the lysis of the infected cell and linked to a supporting filter matrix. Following hybridisation the presence of bound probe is determined by autoradiography. The sensitivity of this assay has been estimated at 50000 copies of HPV (DiGene Diagnostics Inc; Package insert, 1991). In the present study dot-blot assay and NISH were performed on cervical cell specimens obtained from the same patients at the same time and the results correlated with each other and with cytopathological assessment. The results show that dot-blot hybridisation is less sensitive than non-isotopic in situ hybridisation. Even in the presence of koilocytosis, where vegetative replication of the virus occurs, NISH was positive in over twice as many cases as the dot-blot hybridisation assay. In smears within normal cytological limits, where the viral copy number is likely to be considerably lower, the differences were more striking, with NISH detecting the viral genome in $31 \%$ of cases compared with only $5 \%$ by dot-blot analysis $(p<0.001)$. This discrepancy between the two techniques may reflect differences in absolute sensitivity (2.5-12 copies per cell for NISH; 50000 copies for dot blot hybridisation), but may be attributable in part to the detection of additional types by the whole genomic HPV probes used in the NISH assay (Herrington et al, Anderson et al, unpublished observations).

The correlation of NISH and dot-blot results from individual cases shows that NISH positive, dot-blot negative discordant cases are more common $(n=29)$ than dot-blot positive NISH negative cases $(n=5)$. This finding excludes the possibility that sampling error is the sole explanation for the overall differences between NISH and dot-blot analysis. Of the five dot-blot positive, NISH negative cases, three were typed as HPV31/33/35 by dot analysis, and two as HPV16/18. Although it is possible that the three HPV31/33/35 positive cases may be infected with HPV35 (which was not present in the cocktail of NISH probes), this discordance may be due to either sampling error or technical failure affecting both systems.

The data obtained with smears within normal cytological limits indicate that HPV infection is underestimated by regular cytopathological criteria. When the positive cells in these smears were analysed critically, minor nuclear abnormalities were always present. These varied from slight nuclear enlargement to abnormalities of nuclear shape, but, in no case was HPV signal present in a completely normal nucleus. This concurs with both a recent study from this laboratory ${ }^{11}$ and the fact that HPV sequences have never been shown in normal epithelial cell nuclei by in situ hybridisation. ${ }^{25}$ In a recent study from a separate cohort of patients from a sexually transmitted disease (STD) clinic, the prevalence of HPV sequences as determined by NISH in patients with cytologically normal parallel smears was $41 \% .{ }^{10}$ This concurs with data derived by PCR analysis. ${ }^{1617}$ Thus the apparently high prevalence of HPV sequences in patients with apparently normal cervical smears is probably due in part to sampling error between the Papinacolaou stained smear and the sample used for molecular analysis, and in part to the failure of screening cytopathology to detect minor nuclear changes associated with HPV infection. The management of women with human papillomavirus DNA without cytological evidence of a lesion therefore presents clinical difficulties. Such patients are at increased risk of developing preneoplastic and invasive lesions and close follow up screening is required. ${ }^{26}$

In conclusion, we have shown that NISH on cytological smears has potentially greater diagnostic sensitivity than a standardised dot-blot assay for detecting HPV infection. This NISH method is also suitable for a large scale screening programme. It does not require any change in the Papinacolaou smear sampling procedure, being performed on a second specimen collected in the same way. Modification of the procedure has allowed low and high risk types to be differentiated on individual routine cervical smears. ${ }^{10}$ Another advantage is that the same cytotechnician can interpret both the molecular and cytological result. However, to assess the relation between HPV and cervical cancer, data are required on the prevalence of the virus, together with the natural history of the associated lesions on follow up. As a tool to answer these questions, NISH may be used as a sensitive, specific and routinely applicable screening technique.

1 de Villiers EM. Heterogeneity of the human papillomavirus group. F Virol 1989;63:4898-903.

2 Koss LG, ed. Epidermoid carcinoma of the uterine cervix and related precancerous lesions. In: Diagnostic cytology and its histopathologic basis. Vol 1 Philadelphia: J B and its histopathologic basis.

3 Cooper K, Herrington CS, Graham AK, Evans MF, McGee JO'D. In situ human papillomavirus (HPV) genotyping of cervical intraepithelial neoplasia in South African and British patients: evidence for putative HPV integration in vivo. I Clin Pathol 1991;44:400-5.

4 Cooper K, Herrington CS, Graham AK, Evans MF, McGee JO'D. In situ evidence for HPV 16, 18, 33 integration in cervical squamous cell cancer in Britain and South Africa. f Clin Pathol 1991;44:406-9.

5 de Villiers EM, Schneider A, Miklaw H. Human papillomavirus infections in women with and without abnormal cervical cytology. Lancet 1987; ii:703-5.

6 Lorincz AT, Temple GF, Patterson JA, Jenson AB, Kurman RJ, Lancaster WD. Correlation of cellular atypia and human papillomavirus deoxyribonucleic acid sequences in exfoliated cells of the uterine cervix. Obstet Gynecol in exfoliated cells

7 Chimera JA, Anderson SM, Noell H, RizkV. Comparison of nucleic acid hybridisation and cytologic examination for detection of human papillomavirus infection, with evaluation of two commercially available hybridisation kits. Clin Chem 1991;37:260.

8 Wickenden C, Malcolm ADB, Byrne M, Smith C, Anderson MC, Coleman DV. Prevalence of HPV DNA and vira copy numbers in cervical scrapes from women with normal and abnormal cervices. F Pathol 1987;153. 127-35.

9 Pao CC, Lai CH, Wu SY, Young KC, Chang PL, Soong YK Detection of human papillomaviruses in exfoliated cervicovaginal cells by in situ DNA hybridisation analysis. f Clin Microbiol 1989;27:168-73.

10 Herrington CS, Troncone G, Evans MF, McGee JO'D. Screening for high and low risk HPV types in single routine cervical smears by nonisotopic in situ hybridisaroutine cervical smears by nonisotopic in
tion (NISH). Cytopathology 1992;3:71-8.

11 Herrington CS, de Angelis ML, Evans MF, Troncone G McGee JO'D. High risk HPV detection in routine cervica smears: a strategy for screening. 7 Clin Pathol 1992;45: 385-90.

12 Troncone G, Herrington CS, Cooper K, de Angelis ML McGee JO'D. HPV detection in matched cervical smears 
and biopsies by nonisotopic in situ hybridisation. $f$ Clin

13 Toon PG, Arrand JR, Wilson LP, Sharp DS. Human papillomavirus infection of the uterine cervix of women without cytological signs of neoplasia. $\mathrm{Br}$ Med $\mathrm{f}$ 1986;293:1261-4

14 Morris BJ, Flanagan JI, McKinnon KJ, Nightingale BN. Papillomavirus screening of cervical lavages by polymerase chain reaction. Lancet 1988 ;ii: 1368 .

15 Young LS, Bevan IS, Johnson MA, et al. The polymerase chain reaction: a new epidemiological tool for investigating cervical human papillomavirus infection. $\mathrm{Br} \mathrm{Med} \mathcal{f}$ 1989;298:14-18.

16 Bauer HM, Ting Y, Greer CE, et al. Genital human papillomavirus infection in female university students as papilomavirus infection in female university students as
determined by a PCR-based method. $¥ A M A$ 1991; 265:472-7.

17 Schiffman MH, Bauer HM, Lorincz AT, et al. Comparison of Southern blot hybridisation and polymerase chain reaction methods for the detection of human papillomavirus DNA. F Clin Microbiol 1991;29:573-7.

18 Burns J, Graham AK, McGee JO'D. Non-isotopic detection in situ of nucleic acid in cervix: An updated protocol. $f$ Clin Pathol 1988;41:897-9.

19 Herrington CS, Graham AK, McGee JO'D. Interphase cytogenetics III: Enhanced sensitivity and flexibility of digoxigenin labelled DNA probes for HPV detection in cervical biopsies and cell lines. $\mathcal{F}$ Clin Pathol 1991;
44:33-8.

20 Herrington CS, Burns J, Graham AK, Evans MF, McGee $O ' D$. Interphase cytogenetics using biotin and digoxgenin labelled probes I: Relative sensitivity of both reporters for detection of HPV 16 in CaSki cells. $\mathcal{f}$ Clin Pathol 1989;42;592-600.

21 Siegel S. Nonparametric statistics for the behavioral sciences. Tokyo: McGraw-Hill, 1956.

22 Mincheva A, Gissman L, Zur Hausen H. Chromosomal integration sites of human papillomavirus DNA in three cervical cancer lines mapped by in situ hybridisation. Med Microbiol Immunol 1987;176:245-56.

23 Burns J, Redfern DRM, Esiri MM, McGee JO'D Human and viral gene detection in routine paraffin embedded tissue by in situ hybridisation with biotinylated probes. Viral localisation in herpes encephalitis. $₹$ Clin Pathol Viral localisation

24 Mitchell H, Drake M, Medley G. Prospective evaluation of risk of cervical cancer after cytological evidence of human papillomavirus infection. Lancet 1986;i:573-5.

25 Crum CP, Nuovo GJ, Latent or occult HPV infection. In Genital papillomaviruses and related neoplasms. New York Raven Press, 1991:88-105.

26 Ritter DB, Kadish AS, Vermund SH, Romney SL, Villari D, Burk R. Detection of human papillomavirus deoxyribonucleic acid in exfoliated cervico-vaginal cells as a predictor of cervical neoplasia in a high-risk population. Am $₹$ Obstet Gynecol 1988;159:1517-25. 